\title{
THE IMPACT OF ORGANIZATION'S LEADERSHIP AND TRAINING AND DEVELOPMENT ON EMPLOYEES' SATISFACTION IN CASUAL DINING RESTAURANTS IN EGYPT: THE MEDIATING ROLE OF THE WORK ENVIRONMENT
}

\author{
AHMED RADY \\ FACULTY OF TOURISM AND HOTELS, MINIA UNIVERSITY \\ MICHAEL MAGDY ZAKI \\ FACULTY OF TOURISM AND HOTELS, LUXOR UNIVERSITY
}

\begin{abstract}
According to uncertainty management theory, this research examined the effect of the Organization's Leadership and Supervision (OLS) and Training and Development (T\&D) on employees' satisfaction among employees of casual restaurants. This research presented the environment of work as a mediating variable to describe and clarify the correlation between OLS, T\&D and employees' satisfaction. This Research developed all measurements using scales suggested by previous authors. The current research depends on the longitudinal form for data collection. A five-point Likert scale used to test the attitude of the participators toward research variables. 135 Participators shared in this survey are full-time workers employed at casual restaurants located at Greater Cairo. Data collected analyzed using SPSS (23) and AMOS (23) statistical tools. Path analysis approach used to test the research conceptual model. The research found that work environment partially mediates the effect of OLS and T\&D on employees' satisfaction at casual dining restaurants. Casual dining restaurants should develop adequate training programs and care about their work environment to increase employees' satisfaction and adjust their attitude through changing circumstances.
\end{abstract}

KEYWORDS: Casual Dining Restaurant - Employees' Satisfaction - OLS

- Mediating Role - Work Environment - Training and Development.

\section{INTRODUCTION}

There is significant experimental support for the concept that recognized organizational support has a favorable association with employees' positive performance and satisfaction consequences (Muse and Stamper, 2007). This research aims at evaluating the impact of organization's leadership (OLS) and training and development (T\&D) on employees' 
satisfaction and measure the mediating role of the work environment in casual dining restaurants in Egypt.

\section{ORGANIZATION'S LEADERSHIP AND SUPERVISION (OLS)}

Organizational leadership is a binary-converge management process that aims at doing what is the best for individuals and what is the best for the group as a whole altogether. It is also the work and function ethic that helps the individual in any leadership function from above, middle or below the organization (Jada et al., 2019). Previous researches reported that supervisors not only influence employees' state of work-life balance but also have a significant impact on the success of formal and informal work-life procedures (Talukder et al., 2018). Supervisors' support should include the beneficial evaluation of employee's performance, facilitate favorable attitudes towards the work environment in general, profession mentoring, the development of employee's career networks and job direction (Bibi et al., 2018). While the relationship between employees and supervisors is characterized by obligation, faith, long-term orientation, and emotional-social aspects, employees consider support for supervisors as building social interchange (Eisenberger et al., 2002 and Dysvik and Kuvaas 2013). Supervisors are anticipated to act a basic mission in supporting the workers to join the programs of training; encouraging them during all stages of training in terms of budgetary support, chances and assets; engaging them in decision-making; and leading them in applying competences and qualifications that they have gained in the work (Ismail et al., 2007).

\section{WORK ENVIRONMENT}

There are main three key elements in the scope of work, motivation, job satisfaction, and job involvement (Leitmanova and Fekete, 2016). A satisfied employee is fundamental to the success of any organization. Therefore, maintaining satisfied employees should be a primacy of every taskmaster. Satisfied workers are highly loyal, faithful even in bad times because they care about how to take part in an organization's growth and proceed (Grohmann et al., 2014 and Leitmanova and Fekete, 2016). Sell and Cleal (2011) suggested a model on job satisfaction by combine work environment variables and economic variables to evaluate the attitude of workers in serious work environment with high monetary advantages and non-hazardous work environment and low monetary advantages. The study displayed that various psychosocial and work environment variables like social support and work place has direct effect on job satisfaction. 


\section{TRAINING AND DEVELOPMENT (T\&D)}

Training and development indicate the level of training received by employees to improve their knowledge, skills, and attitudes from the organization (Bibi et al., 2018). As organizational models slipped from conventional work-based training to a more tactical development style (Park et al., 2018). The relevance between training transfer and job execution may be better interpreted by the support that training members receive at the workplace when they use their newly obtained skills and information. Support is considered as the most harmonious and critical element estimating training transfer in the wide scope of place and environment of work (Blume et al., 2010 and Lau and Gary, 2013). Business managers expect that the skills and the knowledge obtained from training programs will be conveyed to the work and thus improve work performance. While, training transfer only executes when an assortment of individual and environmental elements derives together and react jointly (Baldwin et al., 2017). Rady and Atya (2017) suggested that training and developing the employees' skills in the manner of dealing with consumers, this is reflected in the service quality.

\section{EMPLOYEES' SATISFACTION}

Satisfied staff greater manage overwork and greater conform (Leitmanova and Fekete, 2016). Satisfied workers intend to further educate themselves to advance their development and to address new obstacles positively (Management Study Guide, 2015). Happy workers are more productive, head for having lower employees' turnover. Since worker satisfaction is one of the essential elements that may influence the implementation of the organization's goals, satisfaction and its maximization have become one of the organizations' clear priorities (Shields et al., 2015).

\section{CASUAL DINING RESTAURANTS}

Casual dining restaurants can be realized as places that introduce moderately priced food and drinks and commonly provide customers with table service, where food items and beverages are served by a service worker at the customers' table (Wall and Berry, 2007). Han et al. (2010), as well as Lee and Hwang (2011), reported that a casual dining restaurant is known as full-service dining whose environment (e.g., atmospherics, décor, and services) and products (e.g., items of foods) are neatly prepared and presented in a unique method. Ryu and Han (2010), as well as Antun et al. (2010), mentioned that in a casual restaurant environment, many quality aspects could influence customers' perception of their restaurant experiences such as quality of food and beverage, the goodness of agent service and the tangible environment. Verma and Gupta (2018) indicated 
that casual dining is one that serves reasonably priced food and beverage in casual atmosphere surroundings; it located between fast food institutions and luxury dining restaurants. Duncan et al. (2015) stated that typical features of a casual restaurant are: 1) customers are waited on by an employee or server, 2) restful atmosphere, 3) reasonably priced menu and 4) typically have televisions in either the dining or bar area and large repeat customer base.

\section{RESEARCH METHODOLOGY}

Researchers developed all measurements using scales suggested by previous authors. Researchers used and applied a nine-item, five-point scale to measure organization's leadership and supervision (OLS) from Best companies group (2018), a six-item, five-point scale to measure training and development from Singam (2015), eight-item, five-point scale to measure employee satisfaction from Bellingham (2014) and a twelveitem, five-point scale to measure work environment from Best companies group (2018) and Leitmanova and Fekete (2016). Participators in this survey are full-time workers at casual restaurants located in Greater Cairo. The researchers applied a simple random sample, where every member of the population has an equal chance of being selected. The current research depends on the longitudinal form for data collection. Saunders et al., (2016) agreed with Djamba, (2002) that the longitudinal form collects data from the same respondents at least two times for examining the change and development over time. Podsakoff et al. (2003) and Chang et al. (2020) reported that a period interlude during the collection of data can minimize the risk of prevalent method variance while at the same time make certain that the participators are still familiar with the study. The first set of questionnaires was sent to these participants by researchers in September 2019 and asked them to determine their experiences of study variables (Organization's leadership and Supervision, Work environment, Training and development, Employee Satisfaction). 185 effective responses were received from the first round of data collection. Subsequently, the researchers contacted these participators about one month later. The second round of the survey gathered data on the training and development following Singam (2015). After another month, the researchers followed Bellingham (2014) and communicated these participators and called them to assess their satisfaction. After another month, the researchers contacted these participators and asked them to evaluate their opinion about the work environment. Finally, the researchers collected effective responses, out of which 135 were usable and used for further analysis from 135 employees, for a response rate of $73(\%)$ percent. Because all the scales were originally developed in English, the researchers converted these questionnaires into 
Arabic to ensure the competence of meaning. The four demographic variables included gender, age, working experience, and period of supervision. Of the participators, 38 were female, and 97 were male, with a mean age of 29 years. They had employed for their works for about 4.8 years and had employed under their current supervision for about 4.1 years.

\section{RESEARCH HYPOTHESIS}

H1: Organization's leadership and supervision is positively correlated with employees' satisfaction in casual dining restaurants.

H2: Training and development is positively correlated with employees' satisfaction in casual dining restaurants.

H3: Organization's leadership and supervision are positively correlated with training and development in casual dining restaurants.

H4: Organization's leadership and supervision have a significant positive impact on the work environment in casual dining restaurants.

H5: Training and development have a significant positive impact on the work environment in casual dining restaurants.

H6: Work environment mediates the effect of organization's leadership and supervision on employees' satisfaction in casual dining restaurants.

H7: Work environment mediates the effect of training and development on employees' satisfaction in casual dining restaurants.

Based on the previous discussions, a research conceptual model is developed which as follow:

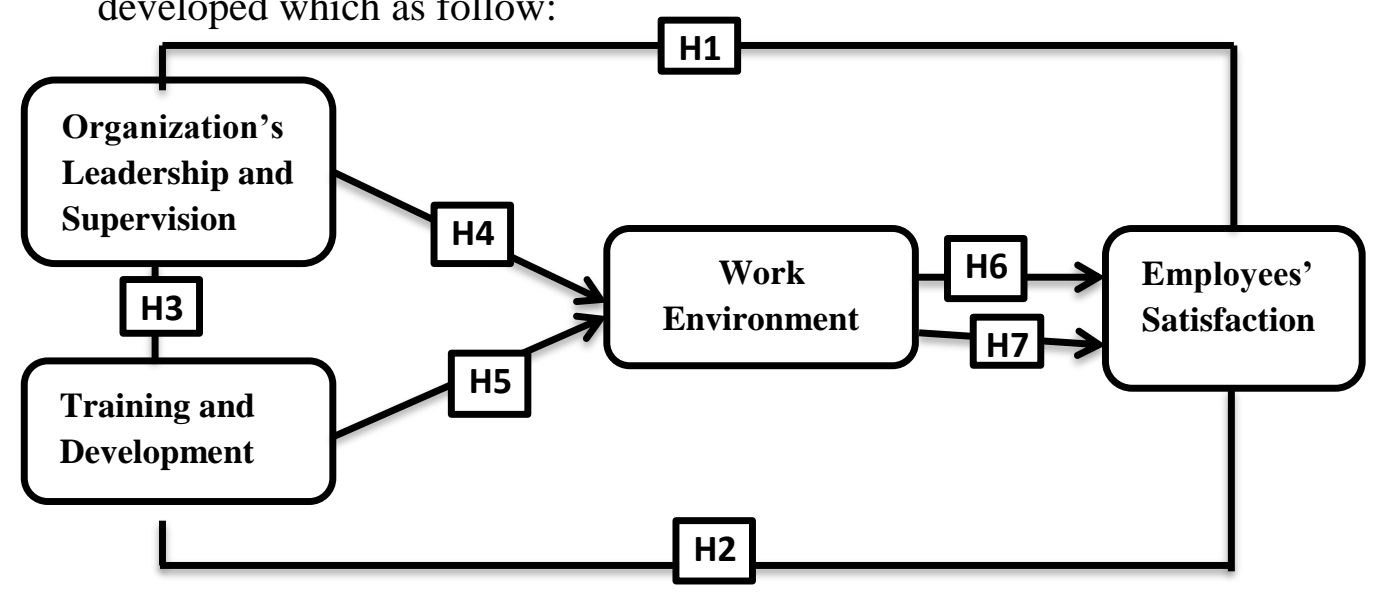

Figure 1: Research conceptual model 


\section{FINDINGS}

\section{VALIDITY AND RELIABILITY}

The researchers put the main constructs of this research in a Confirmatory Factor Analysis (CFA) to test the construct validity. Organization's leadership and supervision (OLS) is set as a one-factor construct consisted of nine items, training and development (T\&D) consisted of six items, employees' satisfaction consisted of eight items, and work environment is composed of 12 items. The CFA suggested that all pertinent questionnaire items loaded significantly on their intentional constructs $(\mathrm{P}<0.05)$ and that the data fully fit the proposed four-factor model (AGFI $=0.87>0.80$, GFI=0.82>0.80). Mac-Callum and Hong (1997) showed that AGFI and GFI values more than 0.8 represent a good model fit. Cronbach's $\alpha$ values of all variables of the research exceed 0.70, supporting enough measurement reliability, Where Hair et al. (2010) contend that Cronbach's $\alpha$ value greater than 0.7 is good for reliability.

\section{DESCRIPTIVE STATISTICS}

ORGANIZATION'S LEADERSHIP AND SUPERVISION (OLS)

Table 1: Descriptive statistics for the structure of OLS in casual dining restaurants

\begin{tabular}{|l|c|c|c|}
\hline \multicolumn{1}{|c|}{ Statements } & M & SD & Rank \\
\hline My supervisor enables me to perform at my best & 4.30 & 0.68 & 1 \\
\hline My manager cares about me as a person & 4.24 & 0.74 & 2 \\
\hline Overall, my supervisor does a good job. & 3.91 & 1.13 & 3 \\
\hline $\begin{array}{l}\text { My supervisor promotes an atmosphere of teamwork } \\
\text { My supervisor is open to hearing my opinion or }\end{array}$ & 3.43 & 0.82 & 4 \\
feedback & 3.94 & 1.27 & 5 \\
\hline $\begin{array}{l}\text { My supervisor helps me develop to my fullest } \\
\text { potential }\end{array}$ & 3.92 & 1.21 & 6 \\
\hline $\begin{array}{l}\text { My supervisor handles my work-related issues } \\
\text { satisfactorily }\end{array}$ & 3.87 & 1.09 & 7 \\
\hline
\end{tabular}




\begin{tabular}{|l|c|c|c|}
\hline My supervisor actively listens to my suggestions & 3.67 & 1.07 & 8 \\
\hline $\begin{array}{l}\text { When I have questions or concerns, my supervisor } \\
\text { can address them }\end{array}$ & 3.64 & 1.09 & 9 \\
\hline
\end{tabular}

Based on the previous table, "My supervisor enables me to perform at my best" comes at a first rank $(\mathrm{M}=4.30, S D=0.68)$, followed by " My manager cares about me as a person" $(\mathrm{M}=4.24, S D=0.74)$. On the other hand, " When I have questions or concerns, my supervisor can address them " is ranked last variable $(\mathrm{M}=3.64, S D=1.09)$.

TRAINING AND DEVELOPMENT

Table 2: Descriptive statistics for training and development in casual dining restaurants

\begin{tabular}{|l|r|r|c|}
\hline \multicolumn{1}{|c|}{ Statements } & M & SD & Rank \\
\hline $\begin{array}{l}\text { I am aware of the advancement opportunities } \\
\text { that exist in the restaurant for me }\end{array}$ & 4.24 & 0.97 & 1 \\
\hline $\begin{array}{l}\text { I had a good idea of what this position involved } \\
\text { before I began }\end{array}$ & 4.21 & 0.81 & 2 \\
\hline $\begin{array}{l}\text { My job allows me to learn } \\
\begin{array}{l}\text { I receive the right amount of recognition for my } \\
\text { work }\end{array}\end{array}$ & 3.96 & 1.06 & 4 \\
\hline $\begin{array}{l}\text { I am fully able to use my learned skills in my } \\
\text { position }\end{array}$ & 3.54 & 0.99 & 5 \\
\hline $\begin{array}{l}\text { I have good training programs that I need to do } \\
\text { my job }\end{array}$ & 3.22 & 1.22 & 6 \\
\hline
\end{tabular}

From the previous table, it showed that "I am aware of the advancement opportunities that exist in the restaurant for me" comes at a first rank $(M=$ 4.24, $S D=0.97$ ), followed by " I had a good idea of what this position involved before I began " ( $M=4.21, S D=0.81$ ). On the other hand, " I have good training programs that I need to do my job " is ranked last variable $(\mathrm{M}=3.22, S D=1.22)$. 
EMPLOYEES' SATISFACTION

Table 3: Descriptive statistics for employees' satisfaction at casual dining restaurants

\begin{tabular}{|c|c|c|c|}
\hline Statements & M & SD & Rank \\
\hline I am satisfied with my income & 4.61 & 0.55 & 1 \\
\hline $\begin{array}{l}\text { I am satisfied with life insurance benefits I } \\
\text { receive }\end{array}$ & 4.53 & 0.69 & 2 \\
\hline $\begin{array}{l}\text { I am satisfied with my possibilities for future } \\
\text { career progression at the restaurant }\end{array}$ & 4.43 & 0.70 & 3 \\
\hline $\begin{array}{l}\text { Other people view my job as a valuable } \\
\text { profession }\end{array}$ & 4.36 & 0.81 & 4 \\
\hline $\begin{array}{l}\text { The amount of work expected of me is } \\
\text { reasonable }\end{array}$ & 4.21 & 0.69 & 5 \\
\hline $\begin{array}{l}\text { Staff in my department communicates } \\
\text { sufficiently with one another }\end{array}$ & 4.10 & 0.82 & 6 \\
\hline I am satisfied with the vacation time I receive & 3.80 & 1.16 & 7 \\
\hline $\begin{array}{l}\text { I am satisfied with the amount of healthcare paid } \\
\text { for me }\end{array}$ & 3.64 & 1.05 & 8 \\
\hline
\end{tabular}

From the previous table, it showed that "I am satisfied with my income" comes at a first rank $(M=4.61, S D=0.55)$, followed by "I am satisfied with life insurance benefits I receive" $(M=4.53, S D=0.69)$. On the other hand, "I am satisfied with the amount of healthcare paid for me" is ranked last variable $(\mathrm{M}=3.64, S D=1.05)$. 
WORK ENVIRONMENT

Table 4: Descriptive statistics for work environment at casual dining restaurants

\begin{tabular}{|c|c|c|c|}
\hline Statements & $\mathbf{M}$ & SD & Rank \\
\hline I'm engaged in meaningful work & 4.37 & 0.77 & 1 \\
\hline $\begin{array}{l}\text { My work activities are personally meaningful to } \\
\text { me }\end{array}$ & 4.18 & 0.94 & 2 \\
\hline I am satisfied with my working in my department & 4.10 & 0.96 & 3 \\
\hline $\begin{array}{l}\text { I would recommend this restaurant as a good place } \\
\text { to work }\end{array}$ & 4.08 & 0.93 & 4 \\
\hline $\begin{array}{l}\text { There is good communication from managers to } \\
\text { employees in the restaurant }\end{array}$ & 4.07 & 0.85 & 5 \\
\hline Most interactions at work are positive & 4.03 & 0.88 & 6 \\
\hline My physical working conditions are good & 4.02 & 0.64 & 7 \\
\hline $\begin{array}{l}\text { I feel positive and up most of the time I am } \\
\text { working }\end{array}$ & 4.01 & 0.95 & 8 \\
\hline I feel free to do things the way I like at work & 3.97 & 0.90 & 9 \\
\hline $\begin{array}{l}\text { There is good communication from employees to } \\
\text { managers in the restaurant }\end{array}$ & 3.96 & 0.94 & 10 \\
\hline I have the tools and resources I need to do my job & 3.88 & 0.96 & 11 \\
\hline I feel like I am a part of the restaurant & 3.87 & 1.03 & 12 \\
\hline
\end{tabular}

From the previous table, it showed that "I'm engaged in meaningful work" comes at a first rank $(M=4.37, S D=0.77)$, followed by "My work activities are personally meaningful to me" $(M=4.18, S D=0.94)$. On the other hand, "I feel like I am a part of the restaurant" is ranked last variable $(\mathrm{M}=3.87, S D=1.03)$. 


\section{TEST OF HYPOTHESES}

The researchers adopt the Pearson correlation coefficient to test $H_{1}$ that experiencing OLS is positively related to employees' satisfaction as follows:

Table 5: Correlation between OLS and employees' satisfaction

\begin{tabular}{|l|l|c|}
\hline \multicolumn{2}{|c|}{ Variables } & $\begin{array}{l}\text { Employees' } \\
\text { Satisfaction }\end{array}$ \\
\hline $\begin{array}{l}\text { Organization's leadership } \\
\text { and Supervision (OLS) }\end{array}$ & Pearson Correlation $(R)$ & $0.75^{* *}$ \\
\cline { 2 - 3 } & Sig. (2-tailed) & 0.000 \\
\cline { 2 - 3 } & $\mathrm{N}$ & 135 \\
\hline
\end{tabular}

${ }^{* *}$ Correlation is significant at the 0.01 level (2-tailed).

Table 5 referred that there is a significant correlation between OLS and employees' satisfaction $(R=0.75, P=0.000)$, this result provides support for the first hypothesis of the research that OLS is positively related to employees' satisfaction. To test $\mathrm{H}_{2}$ that experiencing training and development is positively related to employees' satisfaction, Pearson correlation coefficient was used as follows:

Table 6: Correlation between training and development and employees' satisfaction

\begin{tabular}{|l|l|c|}
\hline \multicolumn{2}{|c|}{ Variables } & $\begin{array}{l}\text { Employees' } \\
\text { Satisfaction }\end{array}$ \\
\hline $\begin{array}{l}\text { Training and } \\
\text { Development }\end{array}$ & Pearson Correlation $(R)$ & $0.71 * *$ \\
\hline & Sig. (2-tailed) & 0.000 \\
\hline & $\mathrm{N}$ & 135 \\
\hline
\end{tabular}

${ }^{* *}$ Correlation is significant at the 0.01 level (2-tailed).

From the previous table it shows that there is a significant correlation between training and development and employees' satisfaction $(R=0.71$, $P=0.000$ ), this result provides support for the second hypothesis of the research that training and development are positively related to employees' satisfaction. To test $\mathrm{H}_{3}$ that experiencing OLS is positively related to training and development, Pearson correlation coefficient was used as follow: 
Table 7: Correlation between OLS and training and development

\begin{tabular}{|l|l|c|}
\hline \multicolumn{2}{|c|}{ Variables } & Training and development \\
\hline \multirow{3}{*}{ OLS } & Pearson Correlation $(R)$ & $0.8^{* *}$ \\
\hline \multirow{3}{*}{} & Sig. (2-tailed) & 0.000 \\
\hline & $\mathrm{N}$ & 135 \\
\hline
\end{tabular}

${ }^{* * *}$ Correlation is significant at the 0.01 level (2-tailed).

From the previous table it shows that there is a significant correlation between OLS and training and development $(R=0.8, P=0.000)$, this result provides support for the third hypothesis of the research that OLS is positively related to training and development. To test $H_{4}$ that experiencing OLS is positively affect the work environment, linear regression coefficients was used as follow:

Table 8: Linear regression coefficients for the influence of OLS on the work environment

\begin{tabular}{|l|l|l|}
\hline \multicolumn{2}{|c|}{ Variables } & OLS \\
\hline & Pearson Correlation (R) & $0.744^{* *}$ \\
\hline Sig. (2-tailed) & 0.000 \\
\hline \multirow{3}{*}{ Work environment } & $\mathrm{R}^{2}$ & 0.55 \\
\cline { 2 - 3 } & ANOVA Sig. & 0.000 \\
\hline & Constant & 1.41 \\
\hline \multirow{2}{*}{ B } & 0.66 \\
\hline & $\mathrm{N}$ & 135 \\
\hline
\end{tabular}

From the previous table, it showed that there is a strong significant correlation between organization's leadership and supervision and work environment $(R=0.744)$, as well as $\left(R^{2}\right)$ that refers to the coefficient of determination is (0.55) suggesting that $55 \%$ of the variation of organization's leadership and supervision was explained by the work environment. ANOVA Sig. (0.000) suggests that the fourth hypothesis of the research is valid.

The following equation for predicting the level of OLS with the information about the level of work environment can be inferred as follow: 


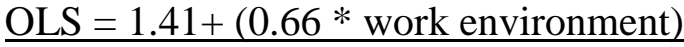

To test $H 5$ that experiencing training and development is positively affect the work environment, linear regression coefficients was used as follow:

Table 9: Linear regression coefficients for the influence of training and development on the work environment

\begin{tabular}{|l|l|l|}
\hline \multicolumn{2}{|c|}{ Variables } & $\begin{array}{l}\text { Training and } \\
\text { development }\end{array}$ \\
\hline \multirow{3}{*}{ Work environment } & Pearson Correlation & $0.793^{* *}$ \\
\hline & Sig. (2-tailed) & 0.000 \\
\hline \multirow{3}{*}{$R^{2}$} & 0.62 \\
\cline { 2 - 3 } & ANOVA Sig. & 0.000 \\
\hline & Constant & 1.163 \\
\hline & B & 0.739 \\
\hline & $\mathrm{N}$ & 135 \\
\hline
\end{tabular}

The previous table indicated that there is a strong significant correlation between work environment and training and development $(R=0.793), R^{2}$ that refers to the coefficient of determination is (0.62) suggesting that $62 \%$ of the variation of the work environment was explained by training and development. ANOVA Sig. (0.000) suggests that the fifth hypothesis of the research is valid.

The following equation for predicting the level of work environment with the information on the level of training and development can be inferred as follow:

$\underline{\text { Work environment }=1.163+(0.739 * \text { training and development })}$

To test $H 6$ that the work environment mediates the effect of the organization's leadership and supervision on employees' satisfaction in casual dining restaurants, researchers follow the path analysis approach. Path analysis is an effective design method for estimating a set of linear regression models where intermediate factors and indirect effects are present due to the association of causal variables (Zhao et al. 2010 and Akanituned, 2012). First, regression is applied to test whether the independent variable OLS is related to the dependent variable, employees' satisfaction. As shown in table (10) OLS is positively and significantly 
related to employees' satisfaction $(R=0.75, P<0.001)$, suggesting that OLs increases the employees' satisfaction. Researchers then test whether the independent variable OLS is related to the mediator, the work environment. As shown in table (8), OLS is positively and significantly related to the work environment $(R=0.744, P<0.001)$. Finally, as shown in table 11, OLS and work environment are both positively and significantly related to employees' satisfaction $(R=0.75, P<0.001)$, the above findings don't support H6 where work environment partially mediates the effect of organization's leadership and supervision on employees' satisfaction at casual dining restaurants.

Table 10: Linear regression coefficients for the influence of OLS on employees' satisfaction

\begin{tabular}{|l|l|c|}
\hline \multicolumn{2}{|c|}{ Variables } & Employees' Satisfaction \\
\hline OLS & Pearson Correlation (R) & $0.75^{* *}$ \\
\hline Sig. (2-tailed) & 0.000 \\
\hline $\mathrm{R}^{2}$ & 0.56 \\
\hline & ANOVA Sig. & 0.000 \\
\hline & $\mathrm{N}$ & 135 \\
\hline
\end{tabular}

** Correlation is significant at the 0.01 level (2-tailed).

Table 11: Multiple regression coefficients for the influence of OLS and work environment on employees' satisfaction

\begin{tabular}{|l|l|l|l|l|l|}
\hline Model & R & $\mathbf{R}^{2}$ & Beta & T & Sig. \\
\hline (Constant) & & & & 9.466 & .000 \\
\hline OLS & & & 0.161 & 2.695 & .008 \\
Work environment & 0.75 & 0.56 & 0.442 & 6.549 & .000 \\
\hline
\end{tabular}

To test $H 7$ that the work environment mediates the effect of training and development on employees' satisfaction at casual dining restaurants, researchers follow the path analysis approach. First regression is applied to test whether the independent variable "training and development" is related to the dependent variable, employees' satisfaction. As shown in table (6) "training and development" is positively and significantly related to 
employees' satisfaction $(R=0.71, P<0.001)$, suggesting that "training and development" increases employees' satisfaction. Researchers then test whether the independent variable "training and development" is related to the mediator, the work environment. As shown in table (9), "training and development" is positively and significantly related to the work environment $(R=0.793, P<0.001)$. Finally, as shown in table 12 , "training and development" and work environment are both positively and significantly related to employees' satisfaction $(R=0.746, P<0.001)$, the above findings don't support $H 7$ where work environment partially mediates the effect of training and development on employees' satisfaction at casual dining restaurants.

Table 12: Multiple regression coefficients for the influence of training and development and work environment on employees' satisfaction

\begin{tabular}{|l|l|l|l|l|l|}
\hline Model & R & $\mathbf{R}^{2}$ & Beta & T & Sig. \\
\hline $\begin{array}{l}\text { (Constant) } \\
\text { training and development }\end{array}$ & & & & 9.614 & .000 \\
Work environment & 0.746 & 0.584 & 0.365 & 5.048 & .000 \\
& & & & 3.713 & .000 \\
\hline
\end{tabular}

Using AMOS program version 23, the research model's goodness of fit was tested $(\mathrm{CFI}=93>90, \mathrm{NFI}=0.83>0.8, \mathrm{AGFI}=0.85>0.8, \mathrm{RMSEA}=$ $0.0483<0.05$ and $\mathrm{GFI}=0.86>0.8)$, these indicators represent a good model fit (Bentler, 1990 and Mac-Callum and Hong, 1997)

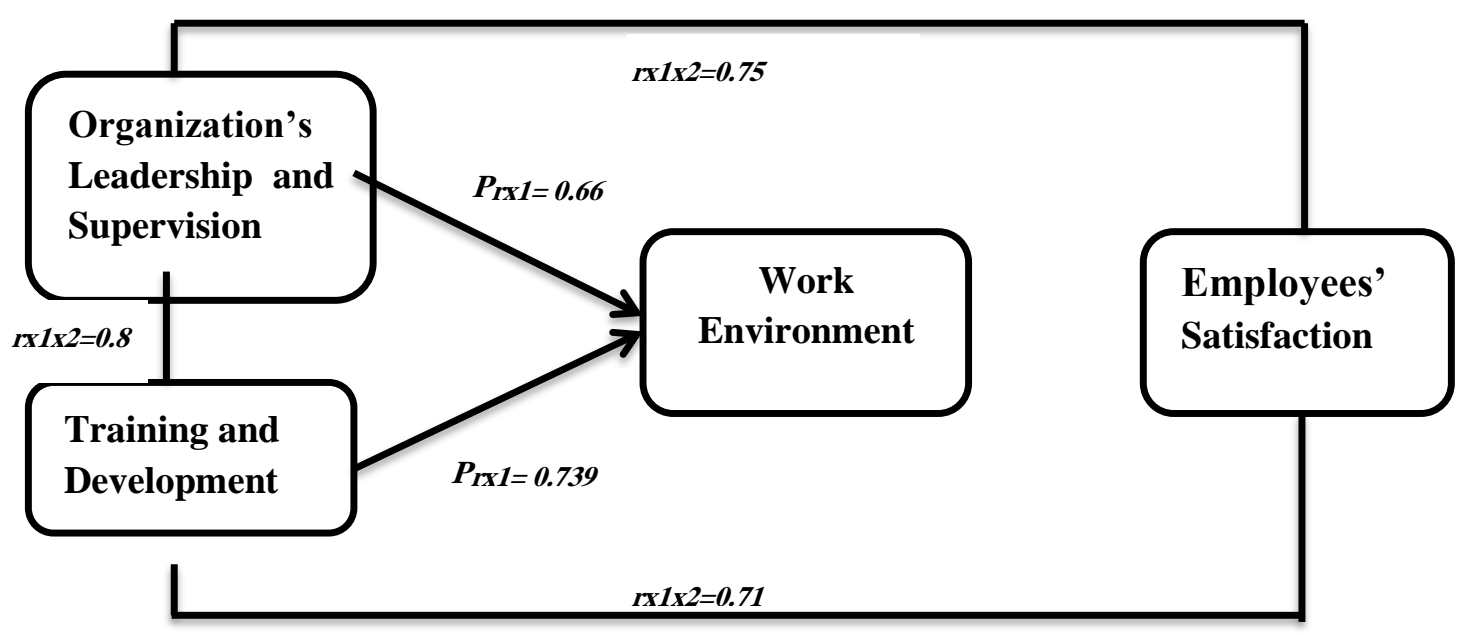

Figure 2: The research model 


\section{CONCLUSION}

Researchers found that OLS and training programs may improve employee performance and work environment (Lau and Gary, 2013). Such a work environment has been proven to raise employees' satisfaction and conform to casual restaurants (Leitmanova and Fekete, 2016). This research further draws on uncertainty management theory (Thau et al., 2009) to illustrate that the OLS and development programs may increase the work environment and, in turn, enhance employees' satisfaction. In this way, this research explicates and verifies that exhibiting OLS while at the same time offering a high level of training and development may further enhance the work environment, which exacerbates the effect on employees' satisfaction.

\section{LIMITATION AND FUTURE RESEARCH}

This research has several and various determining restrictions yet determines opportunities for future studies. First, since the researchers measure employees' satisfaction, the researchers asked employees to evaluate their satisfaction and also evaluate OLS, training, and development, and work environment. However, doing so, entail collecting data on the dependent variable and the independent variables from the same sample. Although, as demonstrated previously, researchers have followed several measures to rule out possible common method problems, in the future scholars may collect data on workers' performance from the leaders and supervisors to directly examine how leadership and training programs and work environment may work jointly in influencing work outcomes. Second, since OLS is found among many places with different cultural characteristics, future researches may test how employees from different cultural orientations may respond differently to OLS. Finally, future researchers should consider some other variables such as organizational behavior and job safety, employees' loyalty.

\section{IMPLICATIONS AND RECOMMENDATIONS}

On the premise of the previous findings, supervisors should provide support to employees, which generally considered useful in helping them accomplish assignments. This research has introduced some empirical evidence on the association between supervisors' support, training and development, work environment, and employees' satisfaction. Casual restaurants should provide adequate training programs and care about their work environment to increase employees' exposure to environmental conditions, strengthen their relations within the restaurant, and adjust their attitude through changing circumstances. Finally, attaining the satisfaction 
of workers is crucial for casual restaurants because thanks to satisfied employees, the restaurants can introduce higher quality services and products, which eventually positively affect the financial aspects and restaurant expansion.

\section{REFERENCES}

Antun, J. M., Frash Jr, R. E., Costen, W., \& Runyan, R. C. (2010). Accurately assessing expectations most important to restaurant patrons: The creation of the DinEX Scale. Journal of Foodservice Business Research, 13(4), 360-379.

Akintunde, A. (2012). Path analysis step by step using excel. Journal of Technical Science and Technologies, 1(1), 09-15.

Baldwin, T. T., Kevin Ford, J., \& Blume, B. D. (2017). The state of transfer of training research: Moving toward more consumer centric inquiry. Human Resource Development Quarterly, 28(1), 17-28.

Best Companies Group (2018). Employee Engagement and Satisfaction Survey,[Online] Available from:https://www .bestcompaniesgroup. com/assessment_tools/programs/BCG_eess.pdf. [Accessed 5th July 2019].

Bellingham, R., (2014). Job Satisfaction Survey. Absolute Advantage Magazine. Wellness Council of America, 3(5).

Bentler, P. M. (1990). Comparative fit indexes in structural models. Psychological bulletin, 107(2), 238-246.

Bibi, P., Ahmad, A., \& Majid, A. H. A. (2018). The impact of training and development and supervisor support on employees' retention in academic institutions: The moderating role of work environment. Gadjah Mada International Journal of Business, 20(1), 113.

Blume, B. D., Ford, J. K., Baldwin, T. T., \& Huang, J. L. (2010). Transfer of training: A meta-analytic review. Journal of Management, 36(4), 1065-1105.

Chang, S. J., van Witteloostuijn, A., \& Eden, L. (2020). Common Method Variance in International Business Research. In Research Methods in International Business (pp. 385-398). Palgrave Macmillan, Cham.

Djamba, Y. K. (2002). Social research methods: qualitative and quantitative approaches. Teaching Sociology, 30(3), 380. 
Duncan, J. L., Josiam, B. M., Kim, Y. H., \& Kalldin, A. C. (2015). Using factor-cluster analysis to segment patrons of casual dining establishments in the United States. British Food Journal, 117, 4.

Dysvik, A., \& Kuvaas, B. (2013). Perceived job autonomy and turnover intention: The moderating role of perceived supervisor support. European Journal of Work and Organizational Psychology, 22(5), 563-573.

Eisenberger, R., Stinglhamber, F., Vandenberghe, C., Sucharski, I. L., \& Rhoades, L. (2002). Perceived supervisor support: contributions to perceived organizational support and employee retention. Journal of applied psychology, 87(3), 565.

Grohmann, A., Beller, J., \& Kauffeld, S. (2014). Exploring the critical role of motivation to transfer in the training transfer process. International Journal of Training and Development, 18(2), 84-103.

Hair, J. F., Black, W. C., Babin, B. J., Anderson, R. E., \& Tatham, R. L. (2010). Multivariate data analysis New Jersy: Pearson Education.

Han, Y. J., Nunes, J. C., \& Drèze, X. (2010). Signaling status with luxury goods: The role of brand prominence. Journal of Marketing, 74(4), 15-30.

Ismail, A., Chandra Segaran, S. C., Cheekiong, T., \& Ong, G. (2007, December). The mediating role of motivation to learn in the relationship between supervisors' role and job performance. In the Sixth Asian Conference of the Academy of HRD (pp. 3-5).

Jada, U. R., Mukhopadhyay, S., \& Titiyal, R. (2019). Empowering leadership and innovative work behavior: a moderated mediation examination. Journal of Knowledge Management.

Lau, P. Y. Y., \& McLean, G. N. (2013). Factors influencing perceived learning transfer of an outdoor management development programme in Malaysia. Human Resource Development International, 16(2), 186-204.

Lee, J. H., \& Hwang, J. (2011). Luxury marketing: The influences of psychological and demographic characteristics on attitudes toward luxury restaurants. International Journal of Hospitality Management, 30(3), 658-669.

Leitmanova, P., \& Fekete, M. (2016). Employee satisfaction survey in the selected types of companies in Slovakia. Comenius Management Review, 10(1), 45-63.

MacCallum, R. C., \& Hong, S. (1997). Power analysis in covariance structure modeling using GFI and AGFI. Multivariate Behavioral Research, 32(2), 193-210. 
Management Study Guide, (2015). Importance of Employee Satisfaction, [Online] Available from:http://www. Managementst udyguide.com /importance-of-employee-satisfaction.htm [Accessed 8th Jan 2020].

Muse, L. A., \& Stamper, C. L. (2007). Perceived organizational support: Evidence for a mediated association with work performance. Journal of Managerial Issues, 517-535.

Park, S., Kang, H. S. T., \& Kim, E. J. (2018). The role of supervisor support on employees' training and job performance: an empirical study. European Journal of Training and Development.

Podsakoff, P. M., MacKenzie, S. B., Lee, J. Y., \& Podsakoff, N. P. (2003). Common method biases in behavioral research: a critical review of the literature and recommended remedies. Journal of applied psychology, 88(5), 879 .

Rady, A. \& Atya, A.M. (2017). Relationship Marketing: Advantages, Limitations and its Effect on the Customer Loyalty at University Hotels. Journal of faculty of tourism and hotels, Alexandria University, Issue. 14, Dec, 85-104.

Ryu, K., \& Han, H. (2010). Influence of the quality of food, service, and physical environment on customer satisfaction and behavioral intention in quick-casual restaurants: Moderating role of perceived price. Journal of Hospitality \& Tourism Research, 34(3), 310-329.

Saunders, M., Thornhill, A., \& Lewis, P., (2016). Research Methods for Business Students. Journal of Chemical Information and Modeling, 53.

Sell, L., \& Cleal, B. (2011). Job satisfaction, work environment, and rewards: Motivational theory revisited. Labour, 25(1), 1-23.

Singam, S. (2015), "Employee Satisfaction Survey Detailed Version", Schemes and Mind Maps for Business Management and Analysis. [Online] Available from:https://www.docsity.com/en/employeesatisfaction-survey-detailed-version/565523/. [Accessed 3th July 2019].

Shields, J., Brown, M., Kaine, S., Dolle-Samuel, C., North-Samardzic, A., McLean, P., \& Robinson, J. (2015). Managing employee performance \& reward: Concepts, practices, strategies. Cambridge University Press.

Talukder, A. K. M., Vickers, M., \& Khan, A. (2018). Supervisor support and work-life balance. Personnel Review.

Verma, V. C., \& Gupta, D. D. (2018). An Investigative Study of Factors Influencing Dining out in Casual Restaurants Among Young Consumers. European Business \& Management, 4(1), 39. 
Thau, S., Bennett, R. J., Mitchell, M. S., \& Marrs, M. B. (2009). How management style moderates the relationship between abusive supervision and workplace deviance: An uncertainty management theory perspective. Organizational Behavior and Human Decision Processes, 108(1), 79-92.

Wall, E. A., \& Berry, L. L. (2007). The combined effects of the physical environment and employee behavior on customer perception of restaurant service quality. Cornell hotel and restaurant administration quarterly, 48(1), 59-69.

Zhao, X., Lynch Jr, J. G., \& Chen, Q. (2010). Reconsidering Baron and Kenny: Myths and truths about mediation analysis. Journal of consumer research, 37(2), 197-206. 